\title{
Growth and Production of Millet Irrigated With Dilutions of Treated Gray Water
}

\author{
Allana Rayra Holanda Sotero ${ }^{1}$, Rafael Oliveira Batista ${ }^{1}$, Mychelle Karla Teixeira de Oliveira ${ }^{1}$, \\ Francisco de Assis de Oliveira ${ }^{1}$, Ricardo André Rodrigues Filho ${ }^{1}$, Hérick Claudino Mendes ${ }^{1}$, \\ Wellyda Keorle Barros de Lavôr ${ }^{1} \&$ Audilene Dantas da Silva ${ }^{1}$ \\ ${ }^{1}$ Universidade Federal Rural do Semi-árido, Mossoró, RN, Brazil \\ Correspondence: Francisco de Assis de Oliveira, Federal Rural University of the Semi-Arid, Mossoró, RN, Brasil. \\ E-mail: thikaoamigao@ufersa.edu.br
}

Received: October 25, 2018

doi:10.5539/jas.v11n3p504

\author{
Accepted: December 1, 2018 \\ Online Published: February 15, 2019 \\ URL: https://doi.org/10.5539/jas.v11n3p504
}

\begin{abstract}
The present work aimed to analyze the effects of the application of dilutions of treated gray water (TGW) in well water (WW) on growth and production of millet cv. Ceará (Pennisetum glaucum). The experiment was carried out in a greenhouse, on the department of agronomic and forestry sciences, at the Federal Rural University of the Semi-Arid (UFERSA), Mossoró, RN, Brazil. The experimental design was randomized blocks with five treatments and six replications, totaling thirty plots. The experiment was carried out in vases with volume of $25 \mathrm{~L}$ containing four plants per vase. The treatments consisted in five dilutions of TGW in WW: T1-100\% WW plus $0 \%$ TGW; T2-75\% WW plus 25\% TGW; T3-50\% WW plus 50\% TGW; T4-25\% WW plus $75 \%$ TGW and T5- $0 \%$ WW plus $100 \%$ TGW. During the experiment it was analyzed the attributes of plant height, number of tillers, number of leaves, stem diameter and total fresh and dry matters. With the results, it was observed that the exclusive irrigation with TGW (T5) promoted better millet development. As the concentrations of TGW increased in dilutions, also increased plant height, number of leaves and tillers. The rise in the number of leaves is associated to the rise in height and tillers, and those are associated to the rise in stem diameter and fresh matter, resulting in better accumulations of dry matter and showing the viability of gray water use to improve forage production and increasing potable water availability to multiple uses.
\end{abstract}

Keywords: Pennisetum glaucum, forage, residual water, biomass, sustainability, reuse

\section{Introduction}

The way to increase availability of sources of water to irrigation is to rationalize its use (Santos Júnior et al., 2013), as well as to reuse water from different activities (Medeiros et al., 2010). The reuse of wastewater on forage production comes as a strategy to sustainable management of water, to reduce future problems of water scarcity. Beyond preventing water sources eutrophication, this technic when used correctly can improve food production because it has nutrients that allow to substitute in part or totally mineral fertilization to cultures, promoting benefits both economic and environmental.

Millet (Pennisetum glaucum) is an easy installing culture when compared to other because it requires less inputs due to its deep and vigorous roots, being efficient on water and nutrients use. According to Silva et al. (2015), millet has high productive potential in areas with low rainfall, being used in adverse conditions, showing to be a good alternative of forage in semiarid regions.

Residual water is being studies in many areas of reuse, presenting promising results (Santos et al., 2016; Alves et al., 2014; Deon et al., 2010). A study carried out in Campinas, SP, with treated domestic wastewater proved that its use promotes water and nutrients to fertilize soil and improve mays productivity (Javarez Júnior et al., 2010). Another study carried out in Apodi, RN, shown that treated domestic wastewater use to irrigate red rice promoted rise on some nutrients tax, such as nitrogen (Brito et al., 2014).

According to Baracuhy et al. (2015), water reuse is a way to reduce environmental pollution, providing water availability to forage irrigation, improving economic development on semiarid region. Among different sources of wastewater, it can be named the gray water, generated from urban and rural residences that come from showers, washbasins, kitchen sinks, tanks and washing machines. In its compositions there are elements from 
soaps and cleaning products, being free from toilet effluents (Feitosa et al., 2011). It has been studying mainly by architecture and civil engineering branches to be reused with non-potable purposes (Guerra, 2016).

Rapoport (2004) states that gray water from kitchen sinks have oil, fat and human food particles in its composition.

In the long run, the use of wastewater can promote salts and heavy metals accumulation in soil to a harmful level to crops development and production (Rusan et al., 2007). Gray water dilutions in well water are done aiming to reduce salts concentration so water's electrical conductivity remain within standards stablished on COEMA's resolution n.2/2017 (Ceará, 2017) for agricultural and forestry purposes. A study carried out in Mossoró, RN, evaluated the effects of cotton irrigation with different dilutions of domestic sewage in two kinds of soil. It was observed that both soils presented increase in sodium content, which is harmful to soil's structure, dissipating soil particles and reducing its permeability (Andrade Filho et al., 2013).

There are reports about wastewater reuse on forage production, for instance, studies developed with water from coffee processing (Fia et al., 2010) and livestock (Piccolo et al., 2013; Saraiva \& Konig, 2013). On literature, studies point to wastewater reuse on forage production (Erthal et al., 2010; Andrade et al., 2014; Homem et al., 2016), however it is scarce studies on gray water reuse on millet development and production.

Thus, this work aimed to analyze the effects of application of treated gray water dilutions in well water on millet's cv. Ceará (Pennisetum glaucum) production and development.

\section{Method}

The experiment was carried out on greenhouse, on the department of agronomic and forestry sciences at the Federal Rural University of the Semi-Arid (UFERSA), Mossoró, RN, State Of Rio Grande do Norte, Brazil $\left(05^{\circ} 12^{\prime} 03.9^{\prime \prime} \mathrm{S} ; 37^{\circ} 19^{\prime} 98^{\prime \prime} \mathrm{W}\right)$. According to Köppen climate classification, the region's climate is classified as $\mathrm{BSh}$, which is a country climate, semiarid, warm and dry, with low altitude and latitude, morphoclimatic domain caatinga, average annual rainfall lower than $650 \mathrm{~mm}$ and average annual temperature higher than $265{ }^{\circ} \mathrm{C}$ (Alvares et al., 2013). In this region the average annual rainfall is $673.9 \mathrm{~mm}$, humidity of $65.9 \%$ (Dias et al., 2010) and average speed of wind is $3.32 \mathrm{~m} \mathrm{~s}^{-1}$ (Morais et al., 2014).

The experimental design used was randomizes blocks with five treatments and six replications, totaling thirty plots. The experiment was carried out in vases with volume of $25 \mathrm{~L}$ containing four plants per vase. The treatments consisted in five dilutions of TGW in WW: T1-100\% WW plus $0 \% \mathrm{TGW}$; $2-75 \% \mathrm{WW}$ plus $25 \%$ TGW; T3-50\% WW plus 50\% TGW; T4-25\% WW plus 75\% TGW and T5-0\% WW plus $100 \%$ TGW. Gray water dilutions are recommended to reduce salt concentration and to identify the most adequate dilution to culture development (Brito, 2014; Medeiros et al., 2015).

As substrate, it was used soil classified as Typic Rhodustuts (Rêgo, 2016), collected from the experimental farm Rafael Fernandes, Mossoro, state of Rio Grande do Norte, Brazil, whose chemical characteristics are presented on Table 1.

Table 1. Chemical characteristic of soil before irrigation with treated gray water dilutions in well water

\begin{tabular}{|c|c|c|c|c|c|c|c|c|c|c|c|c|c|c|c|}
\hline Depth & $\mathrm{pH}$ & $\mathrm{EC}$ & $\mathrm{OM}$ & $\mathrm{P}$ & $\mathrm{K}^{+}$ & $\mathrm{Na}^{+}$ & $\mathrm{Ca}^{2+}$ & $\mathrm{Mg}^{2+}$ & $\mathrm{Al}^{3+}$ & $(\mathrm{H}+\mathrm{Al})$ & SB & $\mathrm{T}$ & CEC & $\mathrm{V}$ & ESP \\
\hline $\mathrm{cm}$ & $\left(\mathrm{H}_{2} \mathrm{O}\right)$ & $\mathrm{dS} \mathrm{m}^{-1}$ & \multicolumn{4}{|c|}{---------- mg dm ${ }^{-3}$---------- } & \multicolumn{7}{|c|}{ - } & \multicolumn{2}{|c|}{---- \% ---- } \\
\hline $0-20$ & 6.10 & 0.41 & 3.31 & 1.90 & 26.90 & 4.70 & 1.10 & 0.70 & 0.00 & 1.49 & 1.89 & 1.89 & 3.37 & 56 & 1 \\
\hline $20-40$ & 4.80 & 0.03 & 2.07 & 1.70 & 26.90 & 4.70 & 0.40 & 1.00 & 0.15 & 1.98 & 1.49 & 1.64 & 3.47 & 43 & 1 \\
\hline
\end{tabular}

Note. pH: Hydrogen potential, EC: electrical conductivity, OM: organic matter, P: phosphorus, K: potassium, $\mathrm{Na}^{+}$: sodium, $\mathrm{Ca}^{2+}$ : calcium, $\mathrm{Mg}^{2+}$ : Magnesium, $\mathrm{Al}^{3+}$ : Aluminum, $(\mathrm{H}+\mathrm{AL})$ : potential acidity, $\mathrm{SB}$ : $\mathrm{Sum}$ of bases, CEC: Cation exchange capacity, ESP: Exchange capacity, V: Base saturation, ESP: exchangeable sodium percentage.

Gray water was collected from a treatment station located on Monte Alegre I settlement $\left(5^{\circ} 3^{\prime} 13.06^{\prime \prime} \mathrm{S}\right.$; $37^{\circ} 27^{\prime} 23.27^{\prime \prime} \mathrm{W}$ ) in Upanema, state of Rio Grande do Norte, Brazil. The gray water produced in the residence is composed by shower, bathroom sink and laundry tanks. The house is inhabited by two people and they have three visitors on weekends, producing average of $80 \mathrm{~L}$ of gray water per day. 
Table 2. Physico-chemical characteristics of treated gray water (TGW) and well water (WW) and its related average (A) and standard deviation (SD)

\begin{tabular}{|c|c|c|c|c|c|c|c|c|}
\hline & \multicolumn{2}{|c|}{$08 / 21 / 2017$} & \multicolumn{2}{|c|}{$09 / 21 / 2017$} & \multicolumn{2}{|c|}{$10 / 16 / 2017$} & \multirow{2}{*}{$\frac{\mathrm{WW}}{\mathrm{A} \pm \mathrm{SD}}$} & \multirow{2}{*}{$\frac{\mathrm{TGW}}{\mathrm{A} \pm \mathrm{SD}}$} \\
\hline & WW & TGW & WW & TGW & WW & TGW & & \\
\hline $\mathrm{Al}\left(\mathrm{mg} \mathrm{L}^{-1}\right)$ & 0.213 & 0.125 & 0.084 & 0.099 & 0.053 & 0.133 & $0.117 \pm 0.085$ & $0.119 \pm 0.018$ \\
\hline As $\left(\mathrm{mg} \mathrm{L}^{-1}\right)$ & 0.000 & 0.000 & 0.000 & 0.000 & 0.000 & 0.000 & $0 \pm 0$ & $0.000 \pm 0.000$ \\
\hline $\mathrm{B}\left(\mathrm{mg} \mathrm{L}^{-1}\right)$ & 0.512 & 0.366 & 0.415 & 0.244 & 0.350 & 0.412 & $0.426 \pm 0.082$ & $0.341 \pm 0.087$ \\
\hline $\mathrm{Ba}\left(\mathrm{mg} \mathrm{L}^{-1}\right)$ & 1.841 & 1.948 & 2.632 & 2.281 & 2.323 & 1.868 & $2.265 \pm 0.399$ & $2.032 \pm 0.219$ \\
\hline $\mathrm{Cr}\left(\mathrm{mg} \mathrm{L}^{-1}\right)$ & 0.064 & 0.105 & 0.012 & 0.000 & 0.013 & 0.004 & $0.030 \pm 0.030$ & $0.036 \pm 0.060$ \\
\hline $\mathrm{Cu}\left(\mathrm{mg} \mathrm{L}^{-1}\right)$ & 0.006 & 0.039 & 0.088 & 0.080 & 0.088 & 0.088 & $0.061 \pm 0.047$ & $0.069 \pm 0.026$ \\
\hline $\operatorname{Mn}\left(\mathrm{mg} \mathrm{L}^{-1}\right)$ & 0.029 & 0.377 & 0.062 & 0.177 & 0.061 & 0.124 & $0.051 \pm 0.019$ & $0.226 \pm 0.133$ \\
\hline $\mathrm{Fe}\left(\mathrm{mg} \mathrm{L}^{-1}\right)$ & 0.030 & 1.404 & 0.087 & 0.498 & 0.094 & 0.471 & $0.070 \pm 0.035$ & $0.791 \pm 0.531$ \\
\hline $\mathrm{Ni}\left(\mathrm{mg} \mathrm{L}^{-1}\right)$ & 0.081 & 0.053 & 0.012 & 0.000 & 0.015 & 0.028 & $0.036 \pm 0.039$ & $0.027 \pm 0.027$ \\
\hline $\mathrm{Cd}\left(\mathrm{mg} \mathrm{L}^{-1}\right)$ & 0.00 & 0 & 0.018 & 0.006 & 0.020 & 0.025 & $0.013 \pm 0.011$ & $0.010 \pm 0.013$ \\
\hline $\mathrm{Pb}\left(\mathrm{mg} \mathrm{L}^{-1}\right)$ & 0.06 & 0.049 & 0.002 & 0.043 & 0.001 & 0.04 & $0.021 \pm 0.034$ & $0.044 \pm 0.005$ \\
\hline $\mathrm{Zn}\left(\mathrm{mg} \mathrm{L}^{-1}\right)$ & 0.018 & 0.291 & 0.031 & 0.076 & 0.034 & 0.076 & $0.028 \pm 0.009$ & $0.148 \pm 0.124$ \\
\hline $\mathrm{pH}$ & 7.1 & 7.5 & 7.12 & 7.59 & 7.05 & 7.97 & $7.090 \pm 0.030$ & $7.693 \pm 0.242$ \\
\hline $\mathrm{EC}\left(\mathrm{dS} \mathrm{m}^{-1}\right)$ & 0.5 & 1.4 & 0.42 & 1.33 & 0.52 & 1.70 & $0.467 \pm 0.050$ & $1.477 \pm 0.197$ \\
\hline $\mathrm{K}^{+}\left(\mathrm{mmol}_{\mathrm{c}} \mathrm{L}^{-1}\right)$ & 0.2 & 1.3 & 0.21 & 1.08 & 0.20 & 1.34 & $0.209 \pm 0.008$ & $1.246 \pm 0.144$ \\
\hline $\mathrm{Na}^{+}\left(\mathrm{mmol}_{\mathrm{c}} \mathrm{L}^{-1}\right)$ & 5.4 & 8.2 & 3.75 & 6.22 & 3.50 & 10.89 & $4.202 \pm 1.008$ & $8.431 \pm 2.345$ \\
\hline $\mathrm{Ca}^{2+}\left(\mathrm{mmol}_{\mathrm{c}} \mathrm{L}^{-1}\right)$ & 0.5 & 3.3 & 0.55 & 4.8 & 0.67 & 1.84 & $0.586 \pm 0.073$ & $3.280 \pm 1.455$ \\
\hline $\mathrm{Mg}^{2+}\left(\mathrm{mmol}_{\mathrm{c}} \mathrm{L}^{-1}\right)$ & 0.3 & 2.1 & 0.20 & 0.86 & 0.43 & 4.98 & $0.322 \pm 0.116$ & $2.638 \pm 2.117$ \\
\hline $\mathrm{Cl}^{-}\left(\mathrm{mmol}_{\mathrm{c}} \mathrm{L}^{-1}\right)$ & 2.9 & 8.5 & 1.20 & 5.40 & 2.00 & 6.40 & $2.022 \pm 0.834$ & $6.778 \pm 1.600$ \\
\hline $\mathrm{CO}_{3}{ }^{2-}\left(\mathrm{mmol}_{\mathrm{c}} \mathrm{L}^{-1}\right)$ & 0.0 & 0.0 & 0.20 & 0.40 & 0.20 & 0.50 & $0.133 \pm 0.115$ & $0.300 \pm 0.265$ \\
\hline $\mathrm{HCO}_{3}^{-}\left(\mathrm{mmol}_{\mathrm{c}} \mathrm{L}^{-1}\right)$ & 2.6 & 7.8 & 1.30 & 2.60 & 2.50 & 7.50 & $2.144 \pm 0.734$ & $5.967 \pm 2.919$ \\
\hline $\mathrm{N}\left(\mathrm{mg} \mathrm{L}^{-1}\right)$ & & & & 40.43 & & 34.56 & & $37.49 \pm 2.940$ \\
\hline $\mathrm{P}\left(\mathrm{mg} \mathrm{L}^{-1}\right)$ & & & & 4.74 & & 2.54 & & $3.640 \pm 1.100$ \\
\hline
\end{tabular}

The applications of gray water dilutions in well water was carried out through an irrigation system of microtubes with a PVC reservoir $(60 \mathrm{~L})$, an circulating pump Metalcorte/Eberle, self-ventilated, EBD250076 model, lateral lines of $16 \mathrm{~mm}$ and microtubes with average flow of $8.5 \mathrm{~L} \mathrm{~h}^{-1}$. The irrigation system applied, daily, the needed volume of dilutions to increase soil humidity until its maximum water retention capacity.

On figure 1 are presented climate data collected inside the greenhouse during the experimental period, minimum (MinTem), medium (MedTem) and maximum (MaxTem) temperatures, minimum (MinRH), medium (MedRH) and maximum (MaxRH) relative humidity and global radiation. Temperatures varied from 26.8 to $29.1{ }^{\circ} \mathrm{C} ; 27.6$ to $29.8{ }^{\circ} \mathrm{C} ; 28.3$ to $30.6{ }^{\circ} \mathrm{C}$, to minimum, medium and maximum, respectively (Figure 1A). For relative humidity, the variations were from 38.9 to $57.8 \%$ for MinRH, 41.8 to $60.3 \%$ for MedRH and 44.7 to $62.9 \%$ for MaxRH (Figure 1B). Solar radiation inside the greenhouse varied from 14.9 to $26.7 \mathrm{MJ} \mathrm{m}^{-2}$ with average of $20.2 \mathrm{MJ} \mathrm{m}^{-2}$ (Figure 1C). 

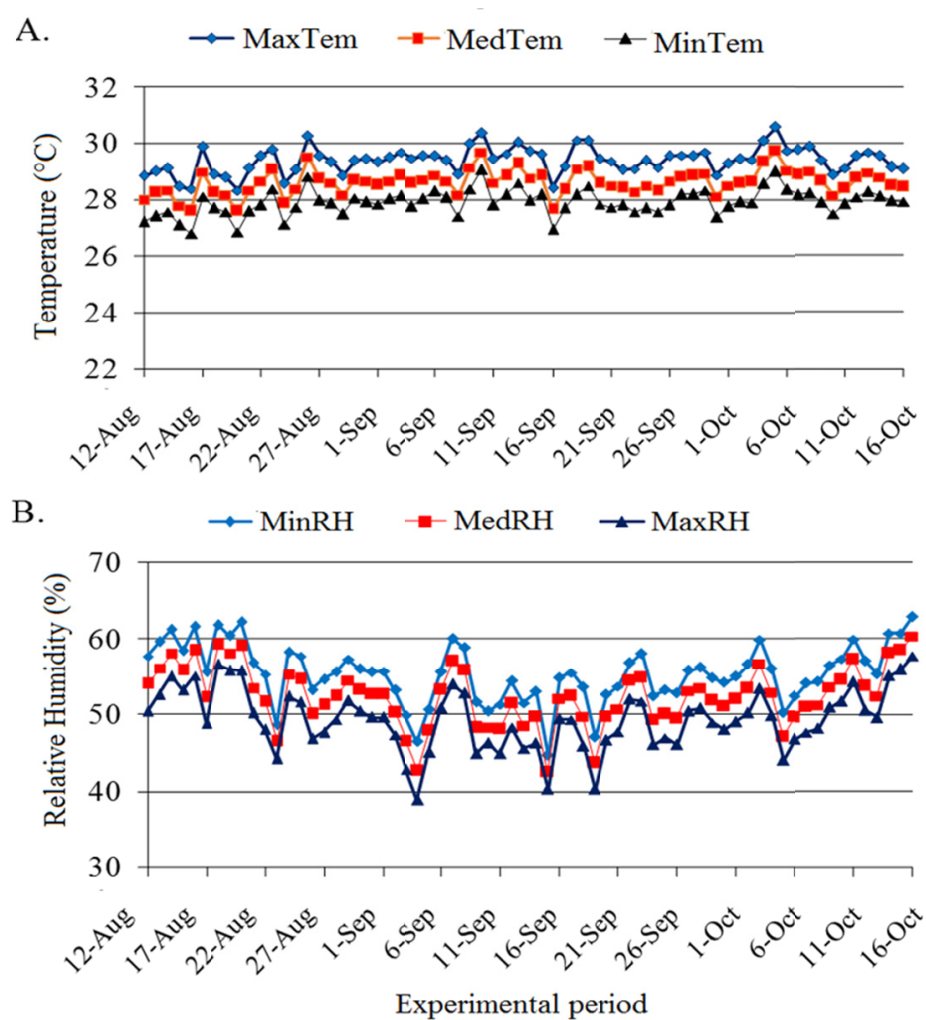

C.

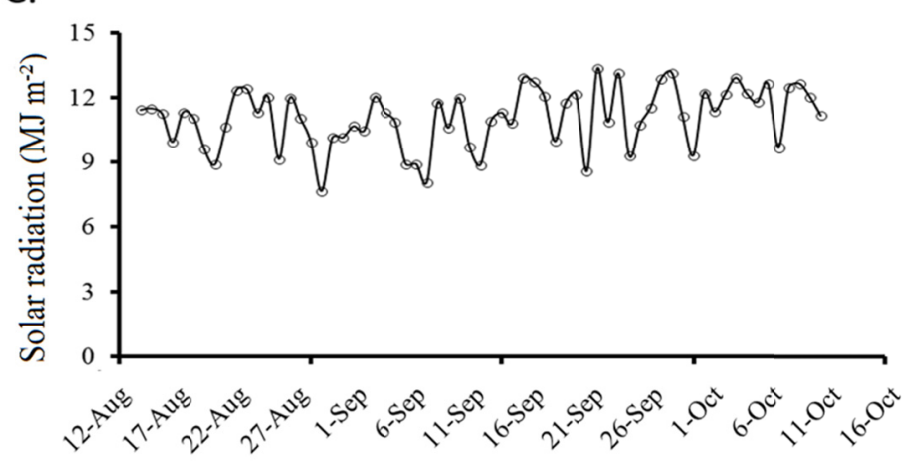

Experimental period

Figure 1. Climate data (A: temperature; B: Air relative humidity; C: solar radiation) obtained during the experimental period

On Table 3 it is presented the volume of water applied during the experiment, showing that it was applied a total volume of $159.4 \mathrm{~L}$ per vase in the end of the experiment for all treatments. Considering that treatments $\mathrm{T} 4$ and T5 received higher volumes of treated gray water, there was economy of 75 and $100 \%$ of well water for forage production, higher than forage production of treatment $\mathrm{T} 1$, that only used well water. 
Table 3. Volume in liters of treated gray water (TGW) dilutions in well water (WW) and applied during the experimental period

\begin{tabular}{|c|c|c|c|c|c|c|c|c|c|}
\hline \multirow{2}{*}{ Treatments } & \multicolumn{2}{|c|}{ 1-20 DAS } & \multicolumn{2}{|c|}{ 21-40 DAS } & \multicolumn{2}{|c|}{ 41-65 DAS } & \multicolumn{2}{|c|}{ Accumulated } & \multirow{2}{*}{ Total } \\
\hline & WW & TGW & WW & TGW & WW & TGW & WW & TGW & \\
\hline & ------ & - & -- & - & ters pe & ase --- & ------ & 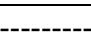 & - \\
\hline $\mathrm{T} 1$ & 71.30 & 0.00 & 30.80 & 0.00 & 57.30 & 0.00 & 159.40 & 0.00 & 159.40 \\
\hline $\mathrm{T} 2$ & 71.30 & 0.00 & 23.10 & 7.70 & 43.00 & 14.30 & 137.40 & 22.00 & 159.40 \\
\hline $\mathrm{T} 3$ & 71.30 & 0.00 & 15.40 & 15.40 & 28.65 & 28.65 & 115.45 & 44.05 & 159.40 \\
\hline $\mathrm{T} 4$ & 71.30 & 0.00 & 7.70 & 23.10 & 14.30 & 43.00 & 93.30 & 66.10 & 159.40 \\
\hline T5 & 71.30 & 0.00 & 0.00 & 30.80 & 0.00 & 57.30 & 71.30 & 88.10 & 159.40 \\
\hline
\end{tabular}

Note. DAS: Days after sowing; T1: 100\% WW plus 0\% TGW; T2: 75\% WW plus 25\% TGW; T3: 50\% WW plus 50\% TGW; T4: 25\% WW plus 75\% TGW and T5: $0 \%$ WW plus 100\% TGW.

Non-destructive evaluations of growth were weekly done through the variables: plant height, number of leaves, number of tillers and number of panicles. At the end of the cycle, it was evaluated development characteristics: height, number of leaves and tillers, stem diameter, number and length of panicles, fresh and dry matter.

The material was collected manually on October $16^{\text {th }}$ of 2017,65 days after sowing. Plants were cut $0.05 \mathrm{~m}$ above the soil taking all its leaves. The fresh matter of the forage was obtained after cutting, when the material was putted in paper bags and weighted. Then, the material was sent to hothouse with forced air circulation on $65^{\circ} \mathrm{C}$ until it gets to constant weight and then it was weighted again to obtain dry matter. Later the material was milled in Willey Mill and kept in plastic bags to go to laboratory analysis.

Data of millet development and production were submitted to analysis of variance, using test $\mathrm{F}$ with $5 \%$ of probability. The means were compared though Tukey test with $5 \%$ of probability. Regression models were chosen based on determination coefficient values and regression equation coefficients, using test $\mathrm{F}$ with $5 \%$ of probability. Statistical analysis of data was carried out with aid of SISVAR program developed by Ferreira (2011).

\section{Results and Discussion}

It was observed that while increase TGW proportion on treatments, plants acquired higher amount of biomass with increase in height, number of leaves and tillers. For height, it was observed no significant difference on the first four weeks and after that plants started to express treatment effects with $5 \%$ of significance and $1 \%$ of significance from fifth week on (Table 4). The better treatment was the one with $100 \%$ of TGW (T1), which presented average height of $112.87 \mathrm{~cm}$ while treatment T1 presented average height of $92.04 \mathrm{~cm}$ (Figure $2 \mathrm{~A}$ ).

Table 4. Summary of analysis of variance to height during miller experiment produced with treated gray water

\begin{tabular}{llllllllll}
\hline \multirow{2}{*}{ Variation sources } & \multirow{2}{*}{ DF } & \multicolumn{7}{c}{ Mean square } \\
\cline { 3 - 8 } & & $10 \mathrm{DAS}$ & $17 \mathrm{DAS}$ & $24 \mathrm{DAS}$ & $31 \mathrm{DAS}$ & $38 \mathrm{DAS}$ & $45 \mathrm{DAS}$ & $52 \mathrm{DAS}$ & $59 \mathrm{DAS}$ \\
\hline Gray water & 4 & $27.16^{\mathrm{ns}}$ & $18.67^{\mathrm{ns}}$ & $610.70^{\mathrm{ns}}$ & $393.7^{*}$ & $696.0^{* *}$ & $387.23^{* *}$ & $426.3^{* *}$ & $471.0^{* *}$ \\
Blocks & 5 & $23.82^{\mathrm{ns}}$ & $31.97^{\mathrm{ns}}$ & $51.73^{\mathrm{ns}}$ & $289.1^{\mathrm{ns}}$ & $330.5^{*}$ & $92.74^{\mathrm{ns}}$ & $410.7^{* *}$ & $201.4^{* *}$ \\
Error & 20 & 24.79 & 13.13 & 234.92 & 115.4 & 115.6 & 7.70 & 37.84 & 38.81 \\
\hline CV $(\%)$ & & 41.39 & 18.01 & 38.54 & 18.02 & 13.40 & 9.72 & 6.65 & 6.29 \\
\hline
\end{tabular}

Note. *, **: significant at $5 \%$ and $1 \%$ of probability, respectively, for $\mathrm{F}$ test. ns: non-significant for $\mathrm{F}$ test. DAS: days after sowing.

The tillers started to show from the beginning of dilutions application, showing significant difference of $1 \%$ on treatments from the $31^{\text {th }}$ day after sowing (Table 5). The treatment with $100 \%$ of TGW presenter better number of tillers, promoting higher biomass with average of 11.5 tillers while the treatment T1 obtained average of 1.5 tiller (Figure 2C). 
Table 5. Summary of variance analysis for the number of tillers during millet experiment produced with treated gray water

\begin{tabular}{|c|c|c|c|c|c|c|c|c|c|}
\hline \multirow{2}{*}{ Variation sources } & \multirow{2}{*}{$\mathrm{DF}$} & \multicolumn{8}{|c|}{ Mean square } \\
\hline & & 10DAS & 17DAS & 24DAS & 31DAS & 38DAS & 45DAS & 52DAS & 59DAS \\
\hline Gray water & 4 & - & - & - & $3.85^{* *}$ & $4.15^{* *}$ & $5.64^{* *}$ & $31.62^{* *}$ & $46.75^{* *}$ \\
\hline Blocks & 5 & - & - & - & $2.46^{*}$ & $2.12^{* *}$ & $1.92^{*}$ & $1.19^{\mathrm{ns}}$ & $4.17^{\mathrm{ns}}$ \\
\hline Error & 20 & - & - & - & 0.78 & 0.32 & 0.64 & 1.39 & 2.04 \\
\hline $\mathrm{CV}(\%)$ & & & & & 52.66 & 32.30 & 39.80 & 39.55 & 38.11 \\
\hline
\end{tabular}

Note. *, **: significant at $5 \%$ and $1 \%$ of probability, respectively, for $\mathrm{F}$ test. ns: non-significant for $\mathrm{F}$ test. DAS: days after sowing.

The number of leaves on the main stem were not significant during part of the experiment, being significantly different from the $7^{\text {th }}$ week (Table 6). On average, the number of leaves on the main stem was bigger in the treatment T1 (7 leaves) and smaller on treatment T5 (3.4 leaves) (Figure 2E).

Table 6. Summary of variance analysis for the number of leaves on the main stem during millet experiment produced with treated gray water

\begin{tabular}{|c|c|c|c|c|c|c|c|c|c|}
\hline \multirow{2}{*}{ Variation sources } & \multirow{2}{*}{$\mathrm{DF}$} & \multicolumn{8}{|c|}{ Mean square } \\
\hline & & 10DAS & 17DAS & 24DAS & 31DAS & 38DAS & 45DAS & 52DAS & 59DAS \\
\hline Gray water & 4 & - & $0.55^{\mathrm{ns}}$ & $2.75^{\text {ns }}$ & $2.26^{\mathrm{ns}}$ & $0.19^{\mathrm{ns}}$ & $3.79^{\mathrm{ns}}$ & $18.89^{* *}$ & $14.85^{* *}$ \\
\hline Blocks & 5 & - & $1.64^{*}$ & $1.61^{\mathrm{ns}}$ & $3.53^{\mathrm{ns}}$ & $2.84^{* *}$ & $4.92^{\mathrm{ns}}$ & $2.88^{\mathrm{ns}}$ & $3.01^{\mathrm{ns}}$ \\
\hline Error & 20 & - & 0.44 & 1.32 & 2.32 & 0.61 & 3.47 & 1.46 & 2.57 \\
\hline $\mathrm{CV}(\%)$ & & & 13.02 & 20.70 & 21.24 & 9.17 & 24.20 & 17.55 & 26.08 \\
\hline
\end{tabular}

Note. ${ }^{*}, * *$ : significant at $5 \%$ and $1 \%$ of probability, respectively, for $\mathrm{F}$ test. ns: non-significant for $\mathrm{F}$ test. DAS: days after sowing.

Despite the number of leaves on main stem do not present big difference during the experiment, the difference can be noticed on the number of total leaves per plant, that increased as increased the number of tillers. This variable presented significant difference of $1 \%$ from the $3^{\text {rd }}$ week after sowing (Table 7) with bigger number of leaves on treatment T5 with average of 53.67 leaves per plant, while on treatment T1 there were 14.09 leaves (Figure 2D).

Table 7. Summary of variance analysis for the number of total leaves during millet experiment produced with treated gray water

\begin{tabular}{|c|c|c|c|c|c|c|c|c|c|}
\hline \multirow{2}{*}{ Variation sources } & \multirow{2}{*}{ DF } & \multicolumn{8}{|c|}{ Mean square } \\
\hline & & 10DAS & 17DAS & 24DAS & 31DAS & 38DAS & 45DAS & 52DAS & 59DAS \\
\hline Gray water & 4 & - & $0.55^{\mathrm{ns}}$ & $120.81^{* *}$ & $110.02^{*}$ & $206.80^{* *}$ & $317.85^{* *}$ & $2717.4^{* *}$ & $591.54^{* *}$ \\
\hline Blocks & 5 & - & $1.61^{*}$ & $11.44^{\mathrm{ns}}$ & $106.33^{*}$ & $126.36^{* *}$ & $103.82^{\mathrm{ns}}$ & $390.0^{\mathrm{ns}}$ & $56.64^{\mathrm{ns}}$ \\
\hline Error & 20 & - & 0.45 & 11.74 & 31.75 & 17.87 & 42.27 & 481.9 & 46.77 \\
\hline $\mathrm{CV}(\%)$ & & & 13.15 & 32.71 & 37.04 & 37.69 & 29.63 & 67.53 & 28.96 \\
\hline
\end{tabular}

Note. ${ }^{*}, * *$ : significant at $5 \%$ and $1 \%$ of probability, respectively, for $\mathrm{F}$ test. ns: non-significant for $\mathrm{F}$ test. DAS: days after sowing.

Panicles started to emerge from the $5^{\text {th }}$ week. With the rise in tiller, more panicles emerged, showing significant difference of $1 \%$ from the $6^{\text {th }}$ week after sowing (table 8) with greater number of panicles the treatment $\mathrm{T} 5$ with mean of 8.46 panicles while treatment $\mathrm{T} 1$ had 1.3 panicles per plant (Figure 2B). 
Table 8. Summary of variance analysis for the number of panicles during millet experiment produced with treated gray water

\begin{tabular}{|c|c|c|c|c|c|c|c|c|c|}
\hline \multirow{2}{*}{ Variation sources } & \multirow{2}{*}{$\mathrm{DF}$} & \multicolumn{8}{|c|}{ Mean square } \\
\hline & & 10DAS & 17DAS & 24DAS & 31DAS & 38DAS & 45DAS & 52DAS & 59DAS \\
\hline Gray water & 4 & - & - & - & - & $0.15^{\text {ns }}$ & $2.66^{* *}$ & $5.56^{* *}$ & $45.12^{* *}$ \\
\hline Blocks & 5 & - & - & - & - & $0.13^{\mathrm{ns}}$ & $1.54^{*}$ & $0.90^{*}$ & $3.10^{\mathrm{ns}}$ \\
\hline Error & 20 & - & - & - & - & 0.09 & 0.48 & 0.23 & 3.31 \\
\hline $\mathrm{CV}(\%)$ & & - & - & - & - & 95.36 & 36.50 & 17.55 & 44.45 \\
\hline
\end{tabular}

$\overline{\text { Note. }}{ }^{*}, * *$ : significant at $5 \%$ and $1 \%$ of probability, respectively, for $\mathrm{F}$ test. ns: non-significant for $\mathrm{F}$ test. DAS: days after sowing.
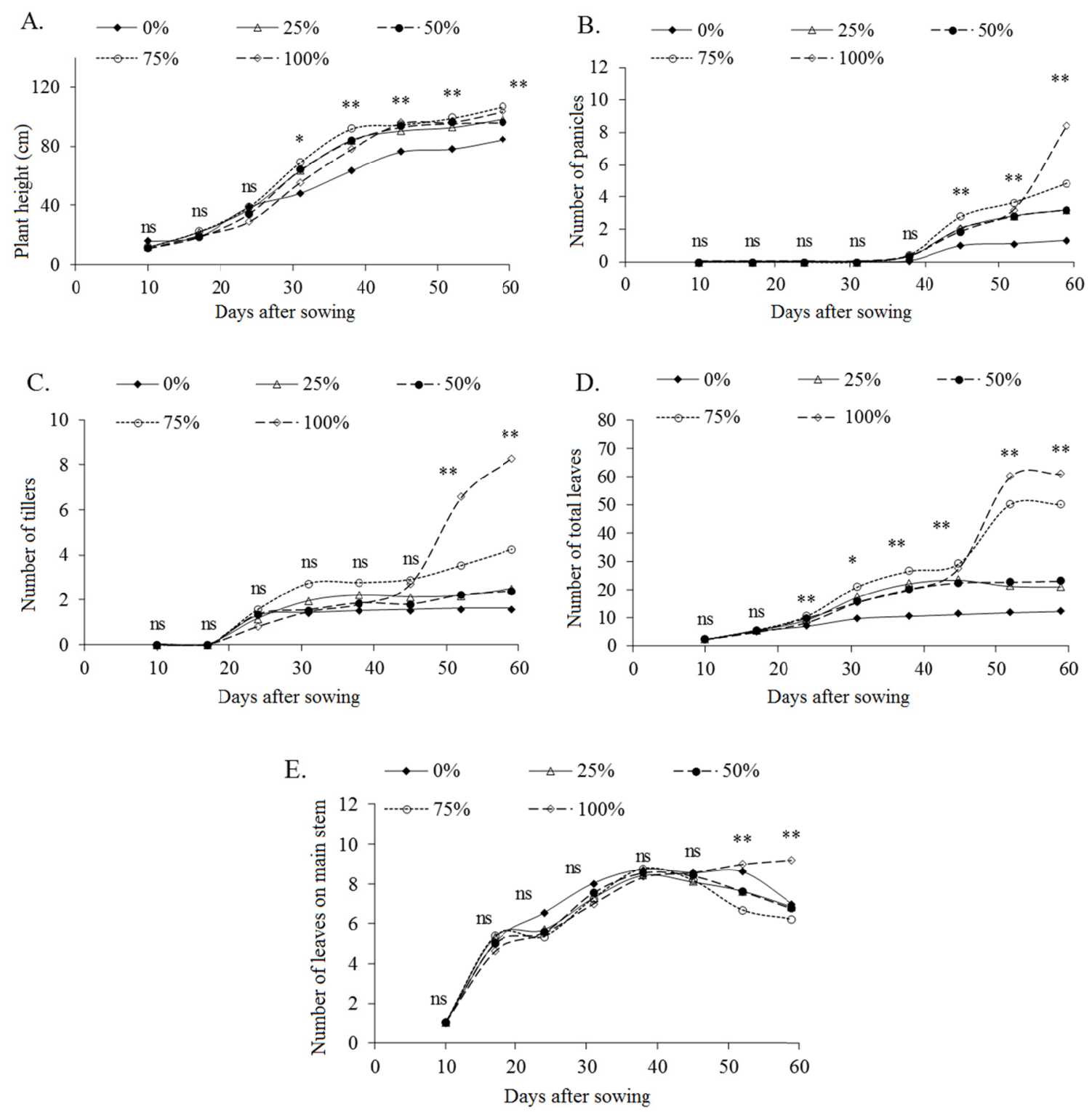

Figure 2. Plant height (A), number of panicles (B), number of tillers (C), number of total leaves (D) and number of leaves on main stem (E) of millet produced with treated gray water 
The analyzed variables were strongly influenced by treatments applied with significant difference of $1 \%$ (tables 9), except panicle length, that did not present significant difference. With these results, it can be identified that gray water application is benefic to growth and development of millet.

Table 9. Summary of variance analysis for fresh matter (FM), dry matter (DM), height (H), number of total leaves (NL), number of tillers (NT), number of panicles (NP), stem diameter (SD), panicle length (PL) fresh panicle matter (FPM) and dry panicle matter (DPM) of millet produces with treated gray water 65 days after sowing

\begin{tabular}{lllllll}
\hline \multirow{2}{*}{ Variation sources } & \multirow{2}{*}{ DF } & \multicolumn{5}{c}{ Mean square } \\
\cline { 3 - 6 } & & FM & DM & H & NL & NT \\
\hline Gray water & 4 & $2028.67^{* *}$ & $251.99^{* *}$ & $459.11^{* *}$ & $545.86^{* *}$ & $40.25^{* *}$ \\
Blocks & 5 & $124.47^{\text {ns }}$ & $24.81^{*}$ & $187.88^{*}$ & $73.41^{\text {ns }}$ & $3.59^{\text {ns }}$ \\
Error & 20 & 81.02 & 8.33 & 56.60 & 33.78 & 1.83 \\
CV $(\%)$ & & 25.58 & 20.77 & 7.67 & 24.12 & 33.93 \\
\hline & & SD & NP & PL & FPM & DPM \\
\hline Gray water & 4 & $1.40^{* *}$ & $43.80^{* *}$ & $2.41^{\text {ns }}$ & $173.37^{* *}$ & $48.82^{* *}$ \\
Blocks & 5 & $8.75^{\text {ns }}$ & $2.84^{\text {ns }}$ & $1.97^{\text {ns }}$ & $7.94^{\text {ns }}$ & $8.78^{\text {ns }}$ \\
Error & 20 & 0.28 & 3.02 & 2.12 & 14.72 & 3.59 \\
CV $(\%)$ & & 16.02 & 41.72 & 15.12 & 35.18 & 29.12 \\
\hline
\end{tabular}

Despite the number of leaves on the main stem present graph with decreasing quadratic behavior with treatments, the number of leaves on tillers presented inverse behavior, culminating to linear growth on number of total leaves. The other variables presented linear growth (height) and quadratic growth (number of tillers, panicles and stem diameter). Panicle length did not present significant difference with treatments (Figures 3 and 4).

A.

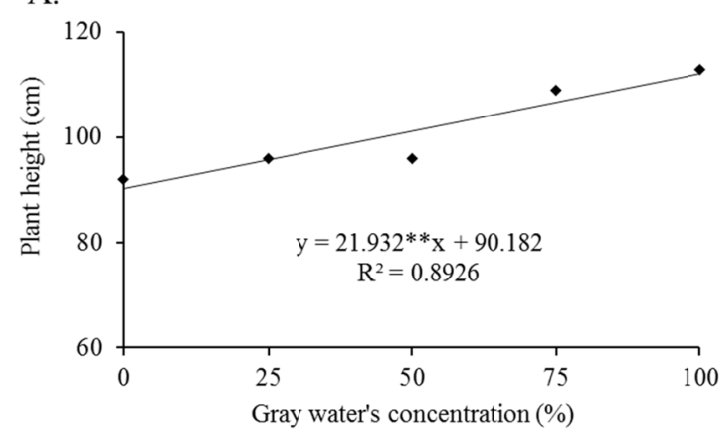

C.

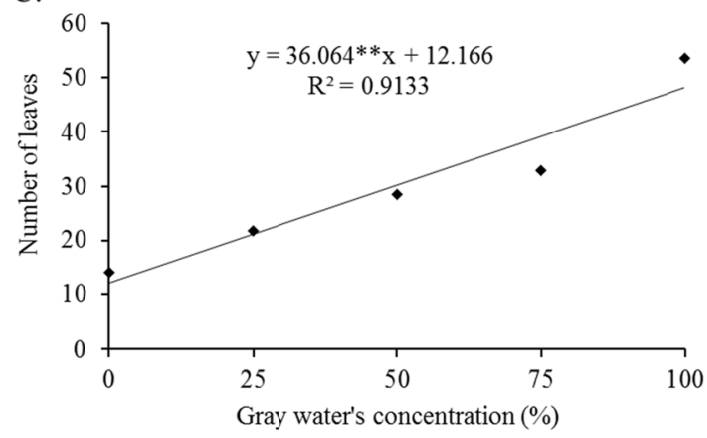

B.

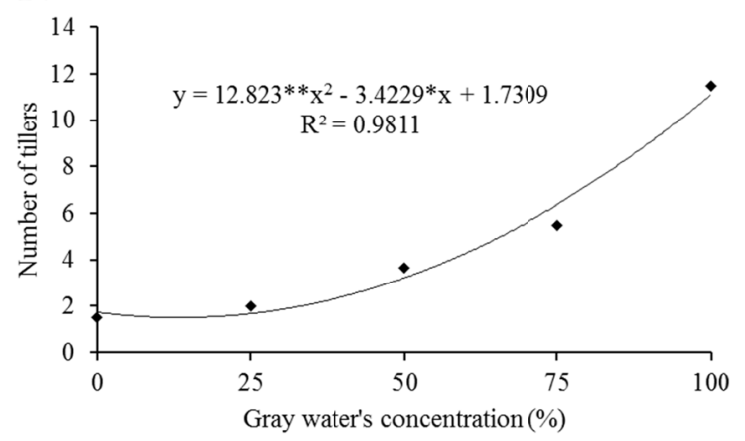

D.

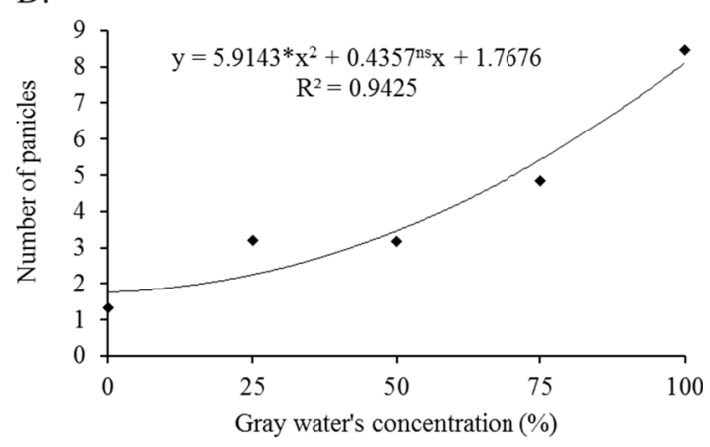


E.

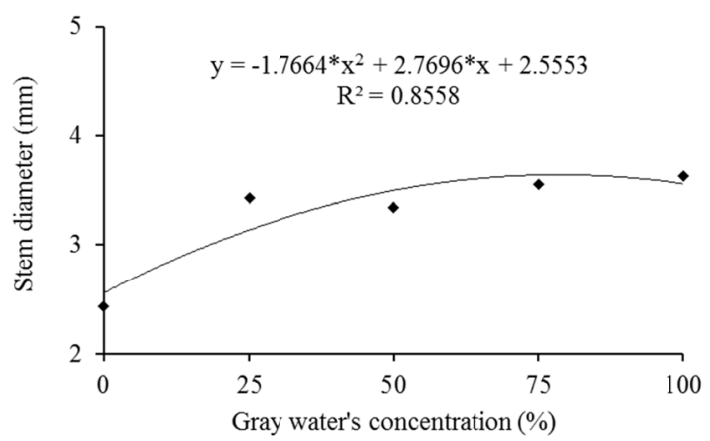

G.

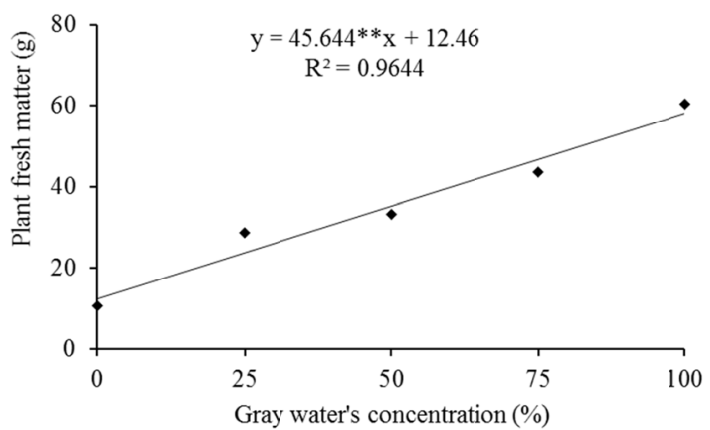

F.

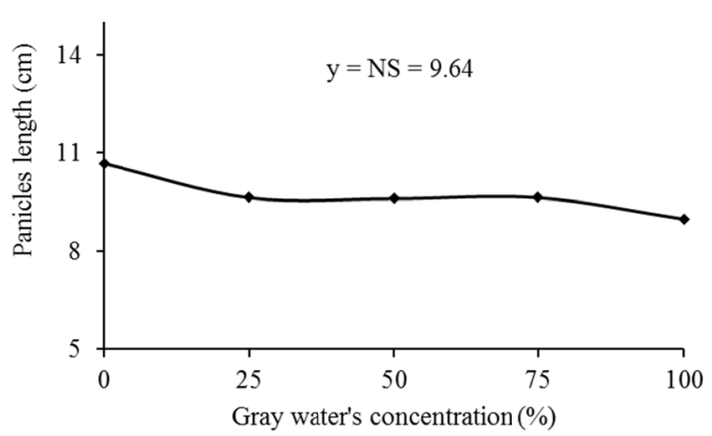

H.

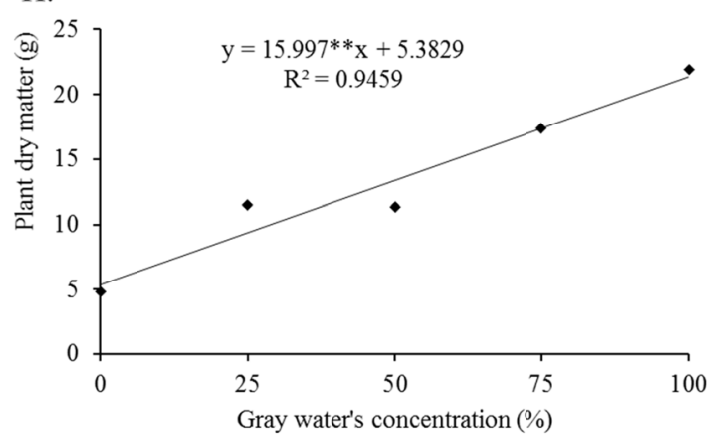

Figure 3. Plant height (A), number of tillers (B), Number of leaves (C), number of panicles (D), stem diameter $(\mathrm{E})$, panicles length $(\mathrm{F})$, plant fresh matter $(\mathrm{G})$ and plant dry matter $(\mathrm{H})$ of millet produced with treated gray water

Millet totally irrigated with treated gray water presented higher values of fresh and dry matter than miller irrigated only with well water. That can be explained by the fact that the gray water presented higher content of macronutrients than well water $\left(600 \%\right.$ of $\mathrm{K}^{+}, 570 \%$ of $\mathrm{Ca}^{2+}$ and $850 \%$ of $\left.\mathrm{Mg}^{2+}\right)$. Gray water also presents significant amounts of nitrogen and phosphorus that favor millet development. Kumar et al. (1985) obtained better biomass of millet with application of nitrogen and zinc. The results are like the results of Javarez Junior (2010) and Santos (2016) that got better productivity of mays and cotton with domestic wastewater.

Nitrogen is a macronutrient with structural function in plant and it is present in gray water in ammoniacal form, from urine not descendent from toilet. Its continuous availability for plant allows it to approximate from its productive potential on growth and production variables.

As increase gray water concentration on treatments dilution, it increased plant height, leaves emission and tiller, and higher values were found on treatment T5 with $100 \%$ of gray water, with height $22.6 \%$ superior to treatment $\mathrm{T} 1$, leaves emission $380 \%$ superior and tiller $767 \%$ superior. As the irrigation with gray water only begun on the $20^{\text {th }}$ day after sowing, it can be inferred that differences in plant height were strongly influenced by the treatments, as well as the number of leaves and tillers, that presented significant difference from the $24^{\text {th }}$ and $52^{\text {nd }}$ days on, respectively. Malafaia et al. (2015), Lira (2016), and Santos (2016) found similar results to mays, sorghum and cotton irrigated with domestic wastewater, respectively, promoting higher values of height and stem diameter in all the experiments, as well as rise in biomass in sorghum and cotton and increase in panicle number in sorghum.

The rise in number of leaves is associated to the rise in height and number of tillers and those are associated to the rise in stem diameter and fresh biomass, resulting in better accumulation of dry mass and showing gray water's viability to forage production. With the rise in tiller number, also occurred rise in panicle number, that did not present significant differences in its length.

\section{Conclusion}

From the results obtained, it can be concluded that irrigation exclusively with treated gray water promoted greater biomass production of millet cv. Ceará (Pennisetum glaucum) being benefic its application to forage production aiming animals feeding. 
It can be concluded that irrigation with gray water increased the nutritional production, obtaining greater production and increasing the availability of water for other purposes.

The results obtained in this scientific study promote the formation of knowledge for the mitigation of water uses for reuse purposes in sustainable agriculture, increasing the availability of drinking water, as well as, if further studies are necessary in this line of research, to evaluate the cumulative effect of the use of gray water on agricultural crops.

\section{References}

Alves, S. M. C., Rebouças, J. R. L., Ferreira Neto, M., Batista, R. O., \& Souza, L. D. (2014). Fertirrigação de girassol ornamental com esgoto doméstico tratado em sistema de hidroponia. Irriga, 19(4), 714-726. https://doi.org/10.15809/irriga.2014v19n4p714

Andrade, A. S., Drumond, L. C. D., Rabelo, D. M. L., Appelt, M. F., Lima, J. C. L., \& Oliveira, V. M. R. (2014). Crescimento de gramíneas forrageiras fertirrigadas com água residuária de suinocultura. Revista Trópica: Ciências Agrárias e Biológicas, 8(2), 59-71.

Baracuhy, V. S., Pereira, J. P. G., Ferreira, A. C., Silva, V. F., \& Schiel, N. (2015). Qualidade das águas cinza tratada com fitorremediação em unidades de produção agrícola. Revista Verde, 10(1), $187-192$. https://doi.org/10.18378/rvads.v10i1.3332

Brito, A. A. F., Ferreira Neto, M., Miranda, N. O., Leal, C. C. P., \& Lira, J. F. B. (2014). Teores de nutrientes em plantas de arroz vermelho irrigado com água residuária doméstica. Irriga, 1(1), 1-10. https://doi.org/10.15809/irriga.2014v1n1p01

Deon, M. D., Gomes, T. M., Melfi, A. J., Montes, C. R., \& Silva, E. (2010). Produtividade e qualidade da cana de açúcar irrigada com efluente de estação de tratamento de esgoto. Pesquisa Agropecuária Brasileira, 45(10), 1149-1156. https://doi.org/10.1590/S0100-204X2010001000014

Erthal, V. J. T., Ferreira, P. A., Pereira, O. G., \& Matos, A. T. (2010). Características fisiológicas, nutricionais e rendimento de forrageiras fertigadas com água residuária de bovinocultura. Revista Brasileira de Engenharia Agrícola e Ambiental, 14(5), 458-466. https://doi.org/10.1590/S1415-43662010000500002

Feitosa, A. P., Lopes, H. S. S., Batista, R. O., Costa, M. S., \& Moura, F. N. (2011). Avaliação do desempenho de sistema para tratamento e aproveitamento de água cinza em áreas rurais do semiárido brasileiro. Engenharia Ambiental, 8(3), 196-206.

Ferreira, D. F. (2011). Sisvar: A computer statistical analysis system. Ciência e Agrotecnologia, 35(6), 1039-1042. https://doi.org/10.1590/S1413-70542011000600001

Fia, R., Matos, A. T., Fia, F. R. L., Matos, M. P., Lambert, T. F., \& Nascimento, F. S. (2010). Desempenho de forrageiras em sistemas alagados de tratamento de águas residuárias do processamento do café. Revista Brasileira de Engenharia Agrícola e Ambiental, 14(8), 842-847. https://doi.org/10.1590/S1415-4366201 0000800008

Gonçalves, R. F. Uso racional de água no meio urbano: Aspectos tecnológicos, legais e econômicos. In S. S. Medeiros, H. R. Gheyi, C. O. Galvão, \& V. P. S. Paz (Eds.), Recursos hídricos em regiões áridas e semiáridas (pp. 163-201). Campina Grande, PB: Instituto Nacional do Semiárido.

Guerra, B. B. (2016). Uso da água como fonte renovável em edificações. Revista de Arquitetura IMED, 5(2), 4-9. https://doi.org/10.18256/2318-1109/arqimed.v5n2p4-9

Homem, B. G. C., Tavares, V. B., Almeida Neto, O. B., Condé, M. S., Ferreira, I. M., Silva, M. D., \& Lara, M. A. S. (2016). Using swine farming wastewater for Signal grass cultivation. Semina: Ciências Agrárias, 37(4) 2539-2548. https://doi.org/10.5433/1679-0359.2016v37n4Sup11p2539

Javarez Júnior, A., Ribeiro, T. A. P., \& Paula Júnior, D. R. (2010). Eficiência do reuso de águas residuárias na irrigação da cultura do milho. Irriga, 15(3) 231-247. https://doi.org/10.15809/irriga.2010v15n3p231

Kumar, V., Ahlawat, V. S., \& Antil, R. S. (1985). Interactions of nitrogen and zinc in pearl millet: 1. Effect of nitrogen and zinc levels on dry matter yield and concentration and uptake of nitrogen and zinc in pearl millet. Soil Science, 139, 351-356. https://doi.org/10.1097/00010694-198504000-00009

Lira, R. B. (2016). Cultivo de sorgo usando água de esgoto doméstico tratado como fonte hídrica. (107f., Tese (Doutorado em Manejo de Solo e Água), Universidade Federal Rural do Semiárido, Mossoró).

Malafaia, G., Rodrigues, A.S. de L., Araújo, F. G. de, \& Leandro, W. M. (2015). Crescimento de plantas de 
milho em solo acrescido de vermicompostos de lodo de curtume e irrigado com água residuária de esgoto doméstico. Revista Ambiente \& Água, 10(4), 847-862. https://doi.org/10.4136/ambi-agua.1625

Medeiros, S. S., Gheyi, H. R., \& Soares, F. A. L. (2010). Cultivo de flores com o uso de água residuária e suplementação mineral. Engenharia Agrícola, 30, 1071-1080. https://doi.org/10.1590/S0100-6916201000 0600008

Oliveira, E. F., Cruz, R. L., Pletsch, T. A., Mazzer, H. R., \& Salomão, L. C. (2010). Efeito do uso de água cinza sobre a vazão de um microaspersor dinâmico. Irriga, 15(3), 258-267. https://doi.org/10.15809/irriga.201 0v15n 3 p 258

Piccolo, M. A., Coelho, F. C., Gravina, G. A., Marciano, C. R., \& Rangel, O. J. P. (2013). Produção de forragem verde hidropônica de milho, utilizando substratos orgânicos e água residuária de bovinos. Revista Ceres, 1(4), 544-551. https://doi.org/10.1590/S0034-737X2013000400014

Rapoport, B. (2004). Águas cinzas: caracterização, avaliação financeira e tratamento para reuso domiciliar e condominial (p. 71).

Rêgo, L. G. S., Martins, C. M., Silva, E. F., Silva, J. J. A., \& Lima, R. N. S. (2016). Pedogenesis and Soil Classification of an Experimental Farm in Mossoró, State of Rio Grande do Norte, Brazil. Revista Caatinga, 29(4), 1036-1042. https://doi.org/10.1590/1983-21252016v29n430rc

Sandri, D., Matsura, E. E., \& Testezlaf, R. (2007). Desenvolvimento da alface Elisa em diferentes sistemas de irrigação com água residuária. Revista Brasileira de Engenharia Agrícola e Ambiental, 11(1), 17-29. https://doi.org/10.1590/S1415-43662007000100003

Santos Júnior, J. A., Barros Júnior, G., Santos, J. K. L., \& Brito, E. T. F. S. (2013). Uso racional da água: Ações interdisciplinares em escola rural do semiárido brasileiro. Ambi-Agua, 8(1), 263-271.

Santos, S. R., Soares, A. A., Kondo, M. K., Araújo, E. D., \& Cecon, P. R. (2016). Crescimento e produção do algodoeiro fertirrigado com água residuária sanitária no semiárido de Minas Gerais. Irriga, 21(1), 40-57. https://doi.org/10.15809/irriga.2016v21n1p40-57

Saraiva, V. M., \& Konig, A. (2013). Produtividade do capim-elefante-roxo irrigado com efluente doméstico tratado no semiárido potiguar e suas utilidades. Holos, 29(1), 28-46. https://doi.org/10.15628/holos. 2013.1251

Silva, K. F., Menezes, F. M. N., Oliveira, M. F., Silva, N. L., Guedes, F. L., Pompeu, R. C. F. F., \& Souza, H. A. (2015). Produção, clorofila e eficiência do uso da água em milheto cultivado em solo de área degradada. Revista Brasileira de Geografia Física, 8(4), 573-584. https://doi.org/10.5935/1984-2295.20150015

\section{Copyrights}

Copyright for this article is retained by the author(s), with first publication rights granted to the journal.

This is an open-access article distributed under the terms and conditions of the Creative Commons Attribution license (http://creativecommons.org/licenses/by/4.0/). 